\title{
An Overview of Bidirectional AC-DC Grid Connected Converter Topologies for Low Voltage Battery Integration
}

\author{
Kaspars Kroics ${ }^{1}$, Oleksandr Husev ${ }^{2}$, Kostiantyn Tytelmaier $^{3}$, Janis Zakis ${ }^{4}$, Oleksandr Veligorskyi ${ }^{5}$ \\ ${ }_{1,4}^{1,4}$ stitute of Industrial Electronics and Electrical Engineering, Riga Technical University, Latvia \\ ${ }^{2,3,5}$ Department of Biomedical Radioelectronics Apparatus and Systems, Chernihiv National University of Technology,
} Ukraina

\begin{tabular}{l} 
Article Info \\
\hline Article history: \\
Received Apr 11, 2018 \\
Revised Jul 2, 2018 \\
Accepted Aug 6, 2018 \\
\hline
\end{tabular}

\section{Keyword:}

AC-DC power converter

Battery storage

Bidirectional converter

Power electronics converter

Single stage converter

\begin{abstract}
Battery energy storage systems are becoming more and more popular solution in the household applications, especially, in combination with renewable energy sources. The bidirectional AC-DC power electronic converter have great impact to the overall efficiency, size, mass and reliability of the storage system. This paper reviews the literature that deals with high efficiency converter technologies for connecting low voltage battery energy storage to an AC distribution grid. Due to low voltage of the battery isolated bidirectional AC-DC converter or a dedicated topology of the non isolated converter is required. Review on single stage, two stage power converters and integrated solutions are done in the paper.
\end{abstract}

Copyright $(0) 2018$ Institute of Advanced Engineering and Science. All rights reserved.

\section{Corresponding Author:}

Kaspars Kroics, Institute of Industrial Electronics and Electrical Engineering, Riga Technical University, 12/1 Azenes Street, Riga, Latvia. Email: kaspars.kroics@ @rtu.lv

\section{INTRODUCTION}

Battery energy storage system (BESS) integration into AC grid allows better utilize different renewable energy sources in the residential electric system and therefore becomes more and more popular. One approach is to connect renewable sources, energy storages and DC loads to the common DC bus interfaced to the utility grid through a centralized bidirectional AC-DC converter [1]. In that case the individual DC-AC converters for each source are eliminated thus improving overall efficiency. Other approach is to connect each BESS through separate bidirectional DC-AC converter to the AC grid. In such a case efficiency is lower but the system becomes modular, the BESS can be installed in a simple way, it can be connected to the existing solar panel or photovoltaic system or even to store energy from the grid at the night when the price of electricity is low and use it during the day (Figure 1). The efficiency, price and power density of the bidirectional DC-AC converter is essential for further development of such an approach.

The most common used battery type in the residential energy storage systems is lithium-ion (Li-ion) battery due to lowest price per $\mathrm{kWh}$ if lifetime is also considered [3]. Due to rapid development of the electrical vehicle industry, a lot of resources are invested into improvement of Li-ion battery cells. This has lead to decreasing of the price of Li-ion batteries, the average price of Li-ion battery including battery management system and cooling is about $400 \mathrm{USD} / \mathrm{kWh}$ [4] but the trend is for the price to go down due to high demand and competition. The recommended energy capacity of the battery for residential application starts from a few $\mathrm{kWh}$ to more than ten $\mathrm{kWh}$ for larger houses that are using electric vehicle daily [5].

To obtain high-voltage of the battery the individual cells must be connected in series. With many cells connected in a string, the possibility of one cell failing is high and this would cause a failure of the 
whole battery if there is no bypass switches implemented. Such connection requires careful cell matching to minimize balancing losses, cell matching is a challenge when replacing a faulty cell. When the voltage of the battery is high then inverter with a state-of-the-art non-isolated (usually traditional buck-boost) converter can be used with only two switches and one inductor therefore the converter is cheap, reliable and efficient.

To use traditional non-isolated topologies, the difference between input voltage (DC bus) and the output voltage (battery) should be less than 4:1 to maintain high efficiency. It means for single phase solution voltage of the battery must be above $150 \mathrm{~V}$. For realization of a $1 \mathrm{kWh}$ Li-ion battery with $48 \mathrm{~V}$ the capacity of the cell must be approximately $21 \mathrm{Ah}$ but for 400 volt level $-0,25 \mathrm{Ah}$. Whereas for the $10 \mathrm{kWh}$ battery, the cell size must be approximately $208 \mathrm{Ah}$ for lower and 25Ah for higher voltage. As the energy density of the state-of-the-art batteries is very high (for example XALT 75 Ah cell [6]), some of them even exceeds 100 $\mathrm{Ah}$, the cells in a range of 40-60Ah are well known and widely used and in the near future the capacity will be even higher.

$48 \mathrm{~V} \mathrm{Li}$-ion modules are available from different manufacturers with different capacity. From the previous calculations can be concluded that low voltage battery is a good choice for storage capacity less than $5 \mathrm{kWh}$. By parallel connection of the modules any required storage capacity can be obtained and system becomes modular. For the connection of the low voltage battery to the grid traditional non-isolated converter topologies is not suitable [7]. The converter mostly requires galvanic isolation to step-up the voltage, and this means a transformer and more switches and predictable lower efficiency therefore. Due to this reason isolated bidirectional or a dedicated non-isolated AC-DC converters plays critical role to decrease price and increase efficiency of the AC coupled BESS for residential application.

AC coupled storage system provides higher flexibility through off-grid modes, it means that the home has power even when the grid is down, grid charging and network support capabilities (for example power factor correction). Very important advantage is that the AC coupled BESS can be fitted to any solar system, any inverter and can be installed easily.

Although AC coupled system is more expensive and less efficient, it becomes more and more popular into the real industrial applications due to easy installation. The fastest developing companies that provides this solution are SMA (www.sma.de), Sonnen (https://sonnen-batterie.com) and Enphase [8]. All of them are using high voltage battery so it is possible to use simpler non-isolated converter topology. The peak efficiency of the SMA converter reaches 97 percents. There are a quite a lot smaller companies that also use AC coupled BESS with 48 V battery, for example, Leonardo Pro 3000/48-16 ac storage system [9] has peak efficiency equal to 95 percent. Figure 1 shows energy storage unit complement with solar energy generation [2]. In [10] is provided analysis of some commercial BESS systems for PV generation under load profile that is close to the real application. Taken into account that BESS provides losses not only during charging but also during discharging overall efficiency for AC coupled BESS is only 61\% [10] therefore can be concluded that highly efficient in the whole load range bidirectional DC-AC converter is highly requested.

Figure 2 shows classification of the topologies for low voltage battery integration into AC grid. The most typical case is to use isolated single or multi stage topologies as these topologies are well known and the control is simple. The use of high gain non isolated topologies can possibly reduce price and size of the converter. Also multiport converter can be used for integration of energy source and battery or different types of storages into the grid. Such type of the converter can be designed with reduced number of components and smaller size. These converters are good option to supply the balance between the renewable energy source generation and load due to variable nature of both. Multiport converters can be classified into three types: non-isolated, partly-isolated and isolated three-port converters. To introduce low voltage BESS isolated or high-gain non-isolated multiport converters are good option. Usually as a multiport converter is used DC-DC converter in combination with traditional DC-AC inverter. The possible reduction of size, costs and losses can be obtained with the development of novel multiport DC-AC single stage converters having less semiconductor switches and passive elements. The paper will provide overview of the most promising topologies for BESS integration into AC grid and gives insight into novel topologies that can be improved further.

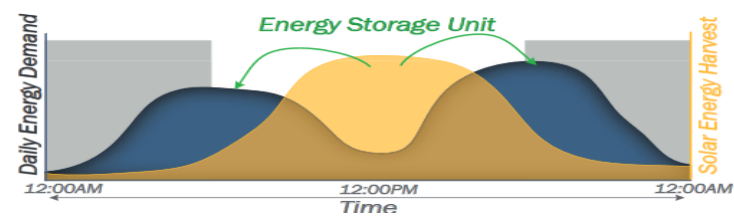

Figure 1. Energy storage unit complement with solar energy generation [2] 


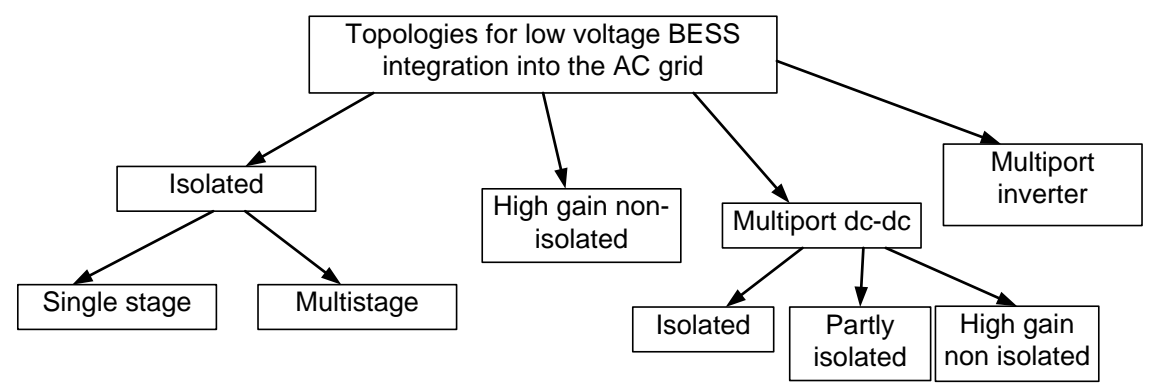

Figure 2. Classification of the topologies for low voltage battery integration in to the AC grid

\section{ISOLATED BIDIRECTIONAL AC-DC CONVERTER TOPOLOGIES}

This chapter provides a brief review of most promising isolated bidirectional AC-DC converters proposed by different research groups in recent years and compares their features in terms of the number of components and reported efficiencies. The structure of the power converter for AC coupled BESS can be divided into single stage and double stage.

\subsection{Isolated Single-stage AC - DC Converter Topologies}

The single-stage AC-DC converters do not have intermediate DC-link storage element. Due to only one conversion stage it is possible to reduce number of semiconductor switches and potentially increase the efficiency and decrease volume, weight, and costs. Most of the topologies including single-stage and twostage topologies use electrolytic capacitors to absorb the $120 / 100 \mathrm{~Hz}$ power produced through the single-stage AC-DC power conversion. This component has a limited lifetime and reduces the reliability of the system. Some topologies let the $100 / 120 \mathrm{~Hz}$ power to go to the battery. This low frequency power ripple produces extra heat inside the battery which results in a reduction of the lifespan of the battery. This problem also must be considered when choosing proper topology.

Flyback based topology is very simple, it is commonly used for low power applications. There are number of different flyback AC-DC unidirectional topologies for low power application. But also it is possible to develop such converter for bidirectional power flow [11], [12]. From Figure 3 can be seen that it is needed to add addition flyback converter to provide bidirectional power flow. So the number of the switches is increased and efficiency is not high. But still it is good solution for low power application where price is very important. More often bidirectional flyback converter is used in two stage topology.

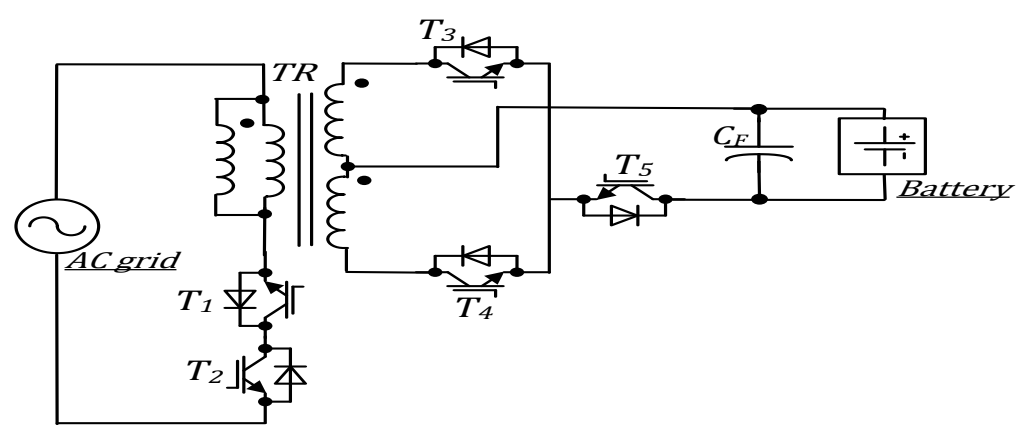

Figure 3. Shematics of a bidirectional flyback converter [11]

Highly efficient AC-DC converter is proposed in [13] and shown in Figure 4. Due to the alternating line voltage, bidirectional switching devices on the AC side have to be employed. These can be realized by an anti-serial connection of two MOSFETs. As a prototype system, a $3.3 \mathrm{~kW}$ battery charger to connect to the single-phase $230 \mathrm{~V}$ AC grid with an output voltage range of $280 \mathrm{~V}$ DC to $430 \mathrm{~V} \mathrm{DC}$. The peak efficiency of the converter exceeds 97.5 percents. Of course, for application to connect $48 \mathrm{~V}$ battery the efficiency will be lower but the topology have low number of switches and control of the converter is not very complicated. Improved control algorithm of similar topology is presented in [14]. Additional benefit gives possibility to develop multilevel converter. 


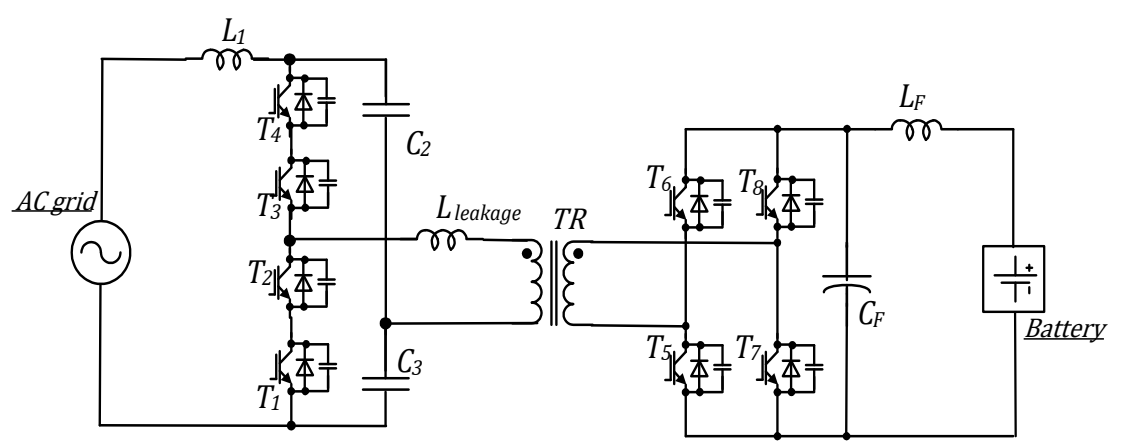

Figure 4. Schematics of a bidirectional single-phase single-stage bidirectional isolated AC-DC converter with PFC [13]

A very simple topology is proposed in [15] ( Figure 5) but for further improvement of the efficiency there is used resonant circuit to provide zero voltage switching plus an extra shunt-active filter to absorb the low frequency AC power. Although in the article is not mention efficiency of the converter, can be predicted that it can reach high value. A similar topology can be applied to the 3 phase AC system with high frequency AC link [16], [17] and usage of bidirectional switches.

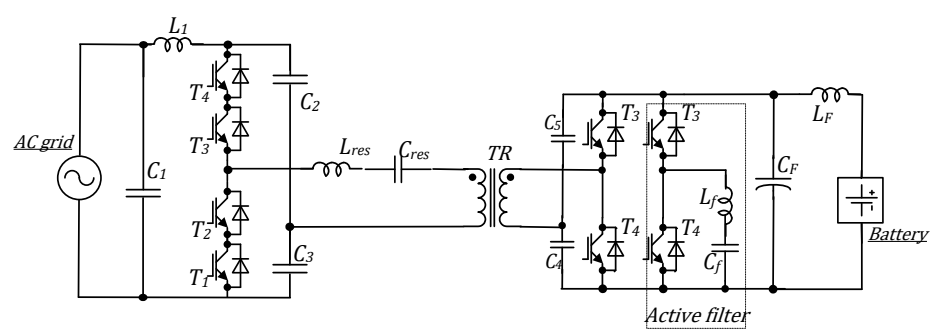

Figure 5. Single-stage topology proposed in [15]

In [18] it is proposed topology with a current source inverter (CSI) (Figure 6) to interface the grid. A DC-DC converter with push - pull or full-bridge in low and high voltage side is used to feed the current to CSI. Contrary to conventional topology, current instead of voltage is fed from the low voltage to high voltage side. The proposed circuit has a quit simple control strategy and a continuous BESS charging and discharging current. In the paper also is presented low scale prototype that shows very smooth waveforms.

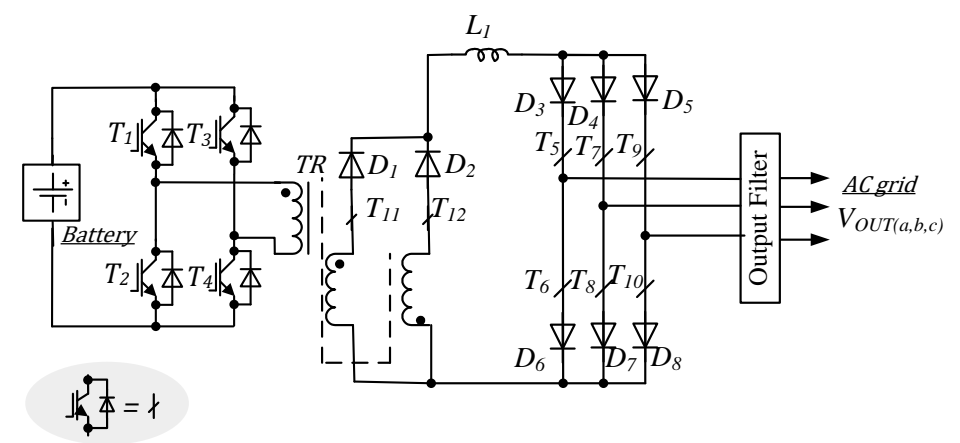

Figure 6. Full-bridge and push-pull in combination with current source inverter proposed in [18] 
Another approach with the use of unipolar voltage switches is shown in Figure 7 [19]. The proposed topology and modulation strategy is implemented in a $20 \mathrm{~kW}$ prototype. Measurements are conducted and show that the methods operate as expected. The method comprises two essential parts, namely a neutralvoltage lift capacitor and a quad active bridge topology. Experimental results show that the load step is stable, the power factor is close to unity, and the phase current THD is less than $5 \%$.

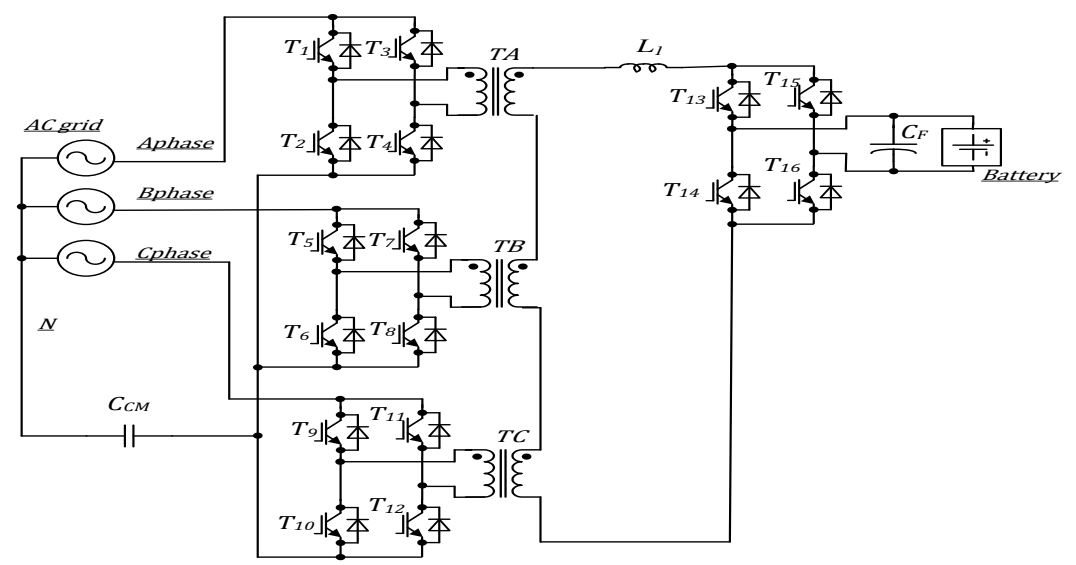

Figure 7. Quad active bridge single stage bidirectional three-phase AC-DC converter with isolation [19]

In [21] is shown that using a single stage dual active bridge topology (Figure 8), it is possible improvement of the efficiency, volume, number of components and cost compared to the traditional dual stage topologies. The experimental prototype is demonstrated in the paper [20] with a 3,7 $\mathrm{kW}$ power, bidirectional power flow and unity power factor. The converter interfaces a $400 \mathrm{~V} \mathrm{DC}$ - bus with the $230 \mathrm{~V}$ AC grid. The high power density prototype converter has high conversion efficiencies - $96 \%$ peak efficiency, a high power factor and low THD.

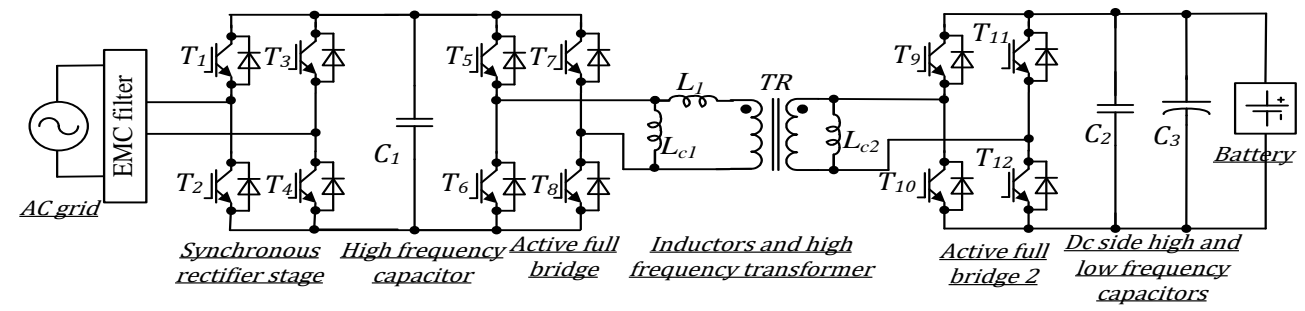

Figure 8. Schematic of the single-phase, single-stage, bidirectional and isolated AC-DC converter topology presented in [20]

The bidirectional isolated single stage converters is used less often that multi stage topologies due to control is more complex, there is no one widely used topology, the calculations and optimization process is complicated. The main benefits of single stage topology are reduced number of semiconductors and volume of magnetic components. Several topologies shows pretty good efficiency, there is many possibilities to increase efficiency further including the use of new topologies and wide band gap devices, also important task is to maintain power factor and THD within the limits

\subsection{Isolated Multi Stage Bidirectional AC-DC Converter Topologies}

A two stage DC-AC converter consists of a bidirectional DC-DC conversion stage and a bidirectional DC-AC stage with PFC functionality. DC-DC stage regulates the DC voltage to the necessary level so that the inverter stage can be directly connected to the AC voltage grid. The AC-DC converter performs the rectification of the $\mathrm{AC}$ voltage into a $\mathrm{DC}$ voltage and regulates the power quality of the grid. At the DC side of the converter is connected a DC-link storage - an inductor to provide current source output or

An Overview of Bidirectional AC-DC Grid Connected Converter Topologies for Low ... (Kaspars Kroics) 
more usually a capacitor to provide voltage DC-bus. As AC-DC stage and the isolated DC-DC conversion stage are separated via the DC energy storage element both systems can be optimized more preciously.

The review of advanced PFC topologies is done in [22] and shows that bidirectional Swiss rectifier have the best performance for 3 phase application in comparison to six-switch rectifier with switchable output polarity and ant parallel six-switch converter combination. High efficiency and power density solution is proposed in [23] that utilizes interleaved multi-cell con Figureuration and works near to the boundary conduction mode. The principle is validated using measurement results on a $200 \mathrm{~W}$ prototype. The realized PFC rectifier achieved an efficiency of $\eta=94.6$ percents and a power factor of 99.3 percents at a very small size.

Detailed review of over 400 papers in field of single-phase AC-DC converters is done in [24], review of multilevel topologies is done in [25]. Multilevel bidirectional converters offer the advantages of low voltage stresses on switches, reduced losses at reduced switching frequency for the same level of performance in terms of reduced harmonics and high power factor at the input AC mains and regulated ripple-free DC output voltage at varying loads. Usually multilevel inverter topologies are used in high voltage applications but due to possibility to reduce THD and reduced losses they become more popular in low voltage applications. More frequently used topologies are diode clamped, flying capacitor and cascaded multilevel converters. The increased costs due to increased number of switches and lower reliability are the main disadvantages of these topologies. Very high efficient AC-DC converter is proposed in [26]. The converter is based on multi-cell converter approach that allows to break the performance barriers of conventional systems by leveraging the advantages of using multiple interleaved low voltage and/or low current converter cells. The DC-AC converter together with DC-DC converter reaches efficiency of 98 percent, power density $2.2 \mathrm{~kW} / \mathrm{dm} 3$ by $3.3 \mathrm{~kW}$ power and $48 \mathrm{~V}$ output voltage.

A few hundred publications can be found in the thematic of isolated bidirectional DC-DC converter. A good comparison of the efficiency of the state-of-the-art converters is done in [21] between one stage dual active bridge (DAB) (Figure 9) and series resonant converter (SCR) and DAB and SRC combination with non-isolated buck-boost converter (Figure 9). The results presented in the paper shows that two stage structure of the DC-DC converter is more efficient and the power density is even higher. The most efficient topology is dual stage SRC converter. The output voltage in the experiments was equal to $15 \mathrm{~V}$, power $2 \mathrm{~kW}$, the efficiency of the converter is above 90 percent in the wide load range. In [27] is proposed to use GaN transistors to increase efficiency of the DAB converter. Dual active bridge topology is investigated in many scientific papers [28], [29], [30] and LLC resonant converter [31], [32], [33] also. The main drawbacks of these topologies are that the number of the components are high and control and optimization is complex.

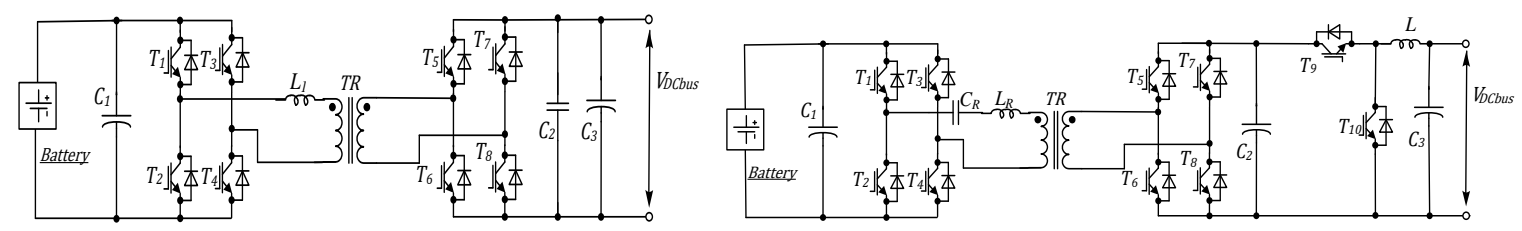

Figure 9. Bi-directional DAB converter and bidirectional dual stage DC-DC converter based on the combination of an isolation stage with a non-isolated voltage converter [25]

Figure 10 shows a bidirectional isolated DC-DC converter based on current fed half-bridge topology. The low-voltage side is a current-source half-bridge converter that functions as a boost converter and an inverter. The high-voltage side is a voltage source half-bridge converter. Lossless snubber capacitors are used to achieve ZVS in the converter. The half-bridge topology has a minimum count of active devices and ZVS is achieved without additional active devices. It has the same total device rating as the full-bridge topology, and a reasonable ripple DC current at the low-voltage side. The drawbacks of the half-bridge topology is that the switching devices are subjected to twice the DC voltage of the battery. Also the split DC capacitors in the half-bridge topology have to withstand the rated current value. The buck and boost operations of the converter have been verified at the rated power of $1.6 \mathrm{~kW}$. An efficiency of more than $94 \%$ was achieved at the rated power [34]. The bidirectional current fed topologies also is proposed in [35]-[39], the efficiency of these converters reaches 95-96 percents. In [40] is analyzed current fed two inductor bidirectional DC-DC converter using resonance but in the paper reported efficiency is not significantly higher.

Int J Pow Elec \& Dri Syst, Vol. 9, No. 3, September 2018 : 1223 - 1239 


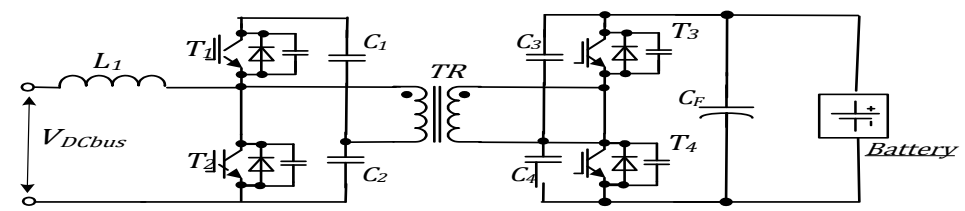

Figure 10. Current fed half bridge converter [34]

In [41] comparison between isolated bi-directional Cuk converter, isolated bidirectional full-bridge converter and isolated bidirectional half-bridge converter is provided. It is found that isolated bi-directional half-bridge converter has the best efficiency-in this case around 90 percent for battery voltage $48 \mathrm{~V}$ and power $2 \mathrm{~kW}$.

Very interesting modular principle offers company "Vicor corporation" [43]. They offers bidirectional resonant DC-DC converter with fixed duty cycle with very high efficiency (Figure 11) in combination with non-isolated converter that regulates current to the load. The converter supports a wide input voltage range and high power. It uses unique sine amplitude converter topology with open loop control. Primary circuit is stacked half bridge and secondary is center tap with synchronous rectification. The converter uses ZVS and ZCS soft switching techniques and operates at $1.1 \mathrm{MHz}$ fixed switching frequency to provide low noise output voltage, high efficiency and high power density. The converter with transformation factor of $1 / 8$ is used to implement $384 \mathrm{~V}$ to $48 \mathrm{~V}$ bidirectional conversions. The proposed converter can achieve more than $96 \%$ efficiency from $15 \%$ load to $100 \%$ load in both directions.

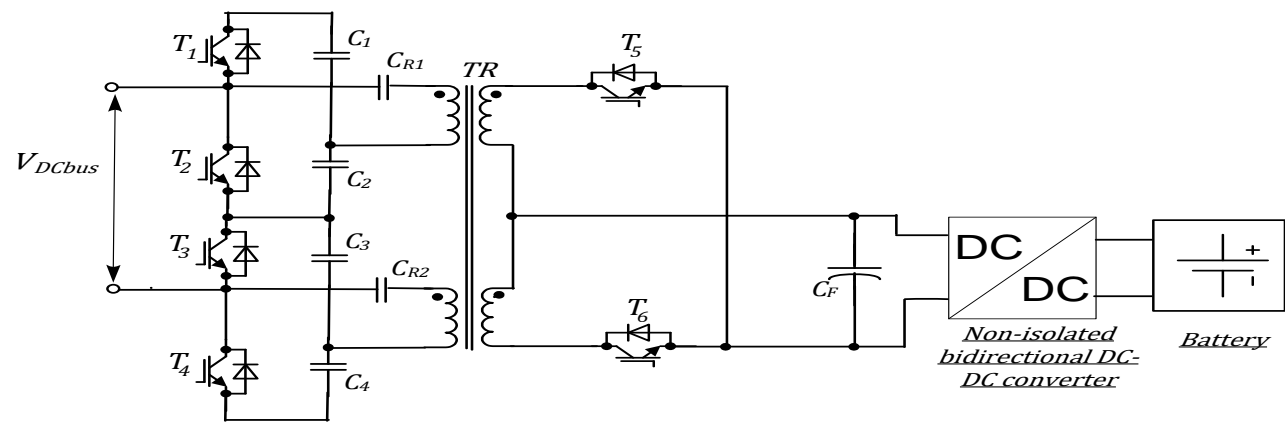

Figure 11. Bidirectional DC-DC converter for high power applications [42]

The performance of the bidirectional converters can be increased by using GaN transistors (as example [44], [45]), or SiC devices [46], [47] also by optimization or by integrating of the magnetic [48], [49], by implementing soft switching techniques [50], [56]-[58], by implementing a novel control algorithms and so on.

\section{NON-ISOLATED BIDIRECTIONAL HIGH STEP UP AC-DC CONVERTER TOPOLOGIES}

To integrate low voltage battery into the grid it is possible to use not only isolated converters but also non isolated converters with high voltage step up/step down functionality, the review of such topologies is given in [54], [55]. The drawbacks of such topologies are complexity, lower efficiency and reliability. Mostly these topologies have unidirectional power flow.

In [56] is proposed high step-up/step-down bidirectional DC-DC converter (Figure 12) in which the coupled inductor $\mathrm{L}_{\mathrm{c}}$ is used. This converter is a combination of the conventional buck-boost and a voltage doublers cell. In some region it is possible to realize zero voltage switching. A 1-kW prototype is demonstrated in the paper operating at $100 \mathrm{kHz}$ switching frequency and built for a battery storage system with voltage $40-60 \mathrm{~V}$ and high voltage side voltage equal to $400 \mathrm{~V}$. The efficiency of the converter is between 94 and 96 percents. The non isolated high step up bidirectional DC-DC converters with coupled inductors also are reported in [57], [58], [59]. In these converters much effort has to be made to overcome the problem associated with the leakage inductor, and the power rating of the coupled-inductor-based converter is limited by the capacity of the magnetic core. 


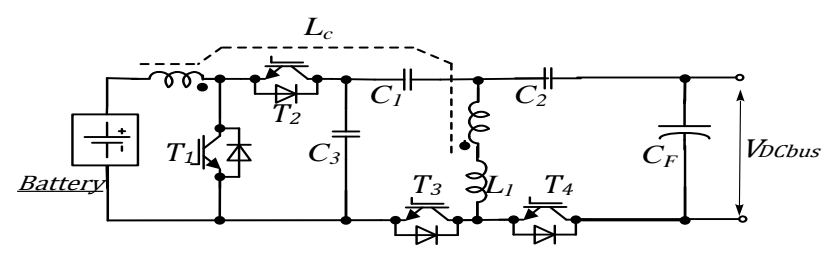

Figure 12. Bidirectional DC-DC converter for high power applications [56]

The switched capacitor converters are analyzed in [60], [61] and have relatively light weight and high efficiency and high power density but have high input current ripple and poor regulation. The switched capacitor bidirectional converter proposed in [61] is composed of only semiconductor switches and capacitors. The prototype of the converter is presented in the paper, $75 \mathrm{kHz}$ switching frequency is selected, the battery voltage is equal to $20 \mathrm{~V}$, output voltage is equal to $173 \mathrm{~V}$ and overall power is $100 \mathrm{~W}$. The reported efficiency is from 95 to 98.5 percent in all load range.

In [62] a transformer is integrated into a conventional non-isolated buck-boost converter to achieve high voltage conversion ratio. The switches are shared by the buck-boost converter and the transformer. Experimental results of $1 \mathrm{~kW}$ prototype that transforms voltage from a $48 \mathrm{~V}$ to $400 \mathrm{~V}$ and vica versa demonstrates peak efficiency equal to $96.6 \%$ for both the step-up and step-down modes.

Multilevel switching cells are introduced into the buck-boost converters in solutions described in [63], [64] to improve the voltage conversion ratio and reduce the voltage stress of power switches. Such multilevel bi-directional converters are attractive for energy storage systems but hard switching reduces the efficiency of the converters and additional circuit or control strategy is needed to keep the voltage balance of the switches. Cascaded and series con Figureurations are adopted to reduce the voltage stresses on switches and increase the voltage conversion ratio of the conventional bidirectional buck-boost converter in [65], [66].

In [68], [69] is proposed bidirectional quadratic boost based inverter. Experimental results in [68] shows that a input voltage of $19 \mathrm{~V} \mathrm{DC}$ is capable of producing a $240 \mathrm{~V}$ AC without the use of a step up transformer. In [70] proposed transformerless Cuk derived high boost DC-AC converter that can reach efficiency even higher than 97 percents. In [67] is presented the study and simulations of a new family of symmetrical hybrid multilevel inverters based on Cuk (Figure 13) and Zeta converters, that are able to high step up/down voltages.

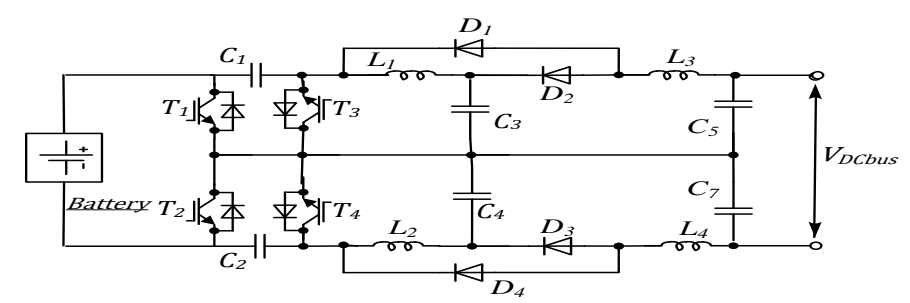

Figure 13. Quadratic bidirectional cuk converter [67]

The non-isolated DC-DC converter together with bidirectional inverter is also worth considering for low voltage battery integration in the AC grid. There is a lack of topologies for bidirectional power flow. The reported efficiency of some converters are high, each of the topology has own drawbacks and advantages so in each particular application must be made deeper analysis to select more appropriate one or even to develop a new topology.

\section{MULTIPORT STORAGE DC-AC SYSTEM WITH RENEWABLE ENERGY INTEGRATION}

A multiport converter is preferable topology if it is possible to place BESS near to the energy source owing to its lower cost and higher power density [71]. Multiport topologies with energy storage more often are used to smoothly supply loads in a stand-alone renewable power system. A review of topologies of three port isolated and non-isolated DC-DC converters for the integration of renewable energy and energy storage system is given in [72], [73]. For applications where the voltage of the renewable energy source is low, the 
isolated topology is good choice for the converter. There are many publications on the isolated three-port DC-DC converters, for example [74], [75], but usually they are used to supply energy to the grid but not vice versa.

Multiport bidirectional converters for a hybrid energy storage system have been reported in [77], [78], [76] and to integrate renewable energy source and BESS [77], [79], [80]. Such topologies allows to utilize two storages for example Li-ion battery as long term storage and ultracapacitor as short term storage. Figure 14. shows one of the possible solution. One of the challenges that must be solved in the converter is energy management between all of ports therefore not only simple-rule method but also the filter method, the fuzzy-control method and the optimization method or other methods are used [76]. In many three port converters full bridge structure are used but also half bridge, current fed and other topologies can be used. Three port triple half bridge bidirectional converter with zero voltage switching is described in [79], the peak efficiency of the $1 \mathrm{~kW}$ prototype is equal to 92 percents.

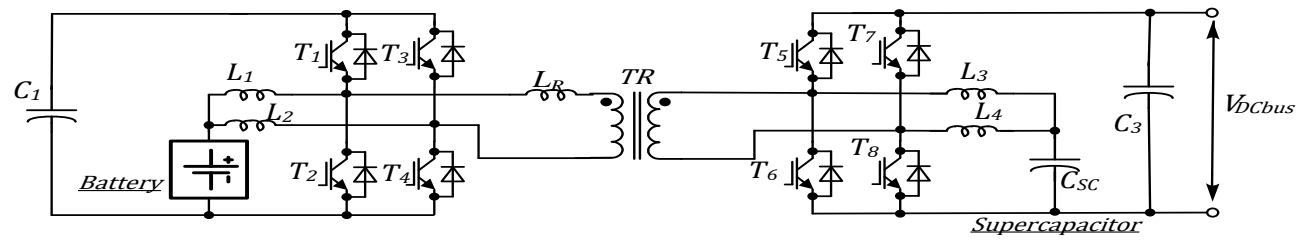

Figure 14. The topology of three port isolated DC-DC converter [76]

A high step-up three-port DC-DC converter for stand-alone power systems is proposed in [81] to integrate PV and battery power. In the proposed topology, two coupled inductors are employed as voltage gain extension cells for high voltage output applications. The highest converter efficiency is measured as 90 percents at $110 \mathrm{~W}$ power.

A multi input zero voltage switching bidirectional DC-DC converter has been proposed in [82]. A 6 $\mathrm{kW}$ prototype was built and tested to verify the power flow control. The reported efficiency of the prototype is around 91 percent by input voltages equal to 20 volts and by output voltage 430 volts.

A transformer coupled multiport zero voltage switching bidirectional DC-DC converter with wide input range is described in [83] (Figure 15). A prototype rated at $3.5 \mathrm{~kW}$ and $100 \mathrm{kHz}$ switching frequency using all full-bridges wa successfully tested. The efficiency is not reported in the paper. Very similar topology is used in [84], [85].

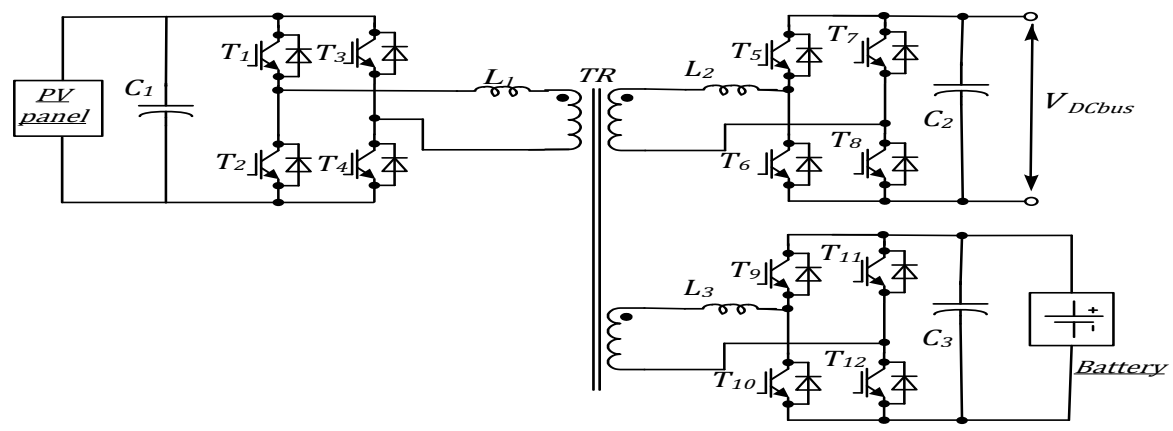

Figure 15. The topology of three port isolated DC-DC converter [83]

In [84] the prototype with low voltage ports voltages equal to $14 \mathrm{~V}$ and $42 \mathrm{~V}$ and DC bus voltage equal to $300 \mathrm{~V}$ and $100 \mathrm{kHz}$ switching frequency exceeds 91 percent efficiency by wide load range. In [86] is proposed high step up three port converter, the prototype of the converter with $250 \mathrm{~W}$ power, a low voltage input port $24 \mathrm{~V}$, a bidirectional battery port $48 \mathrm{~V}$, and a high voltage port with $400 \mathrm{~V}$ for output is implemented. The reported efficiency are above 94 percents at all load conditions.

Only a few papers can be found on the multi port single stage inverters [87]-[91]. In [87] (Figure 16) is proposed a soft-switched isolated three port single stage inverter for power management of a PV system, a battery, and an AC load. Converter can be turned on under the zero voltage switching condition therefore 
efficiency is high. The converter has the advantages of using less active switches and that all the switches are capable of being turned on under the ZVS condition.

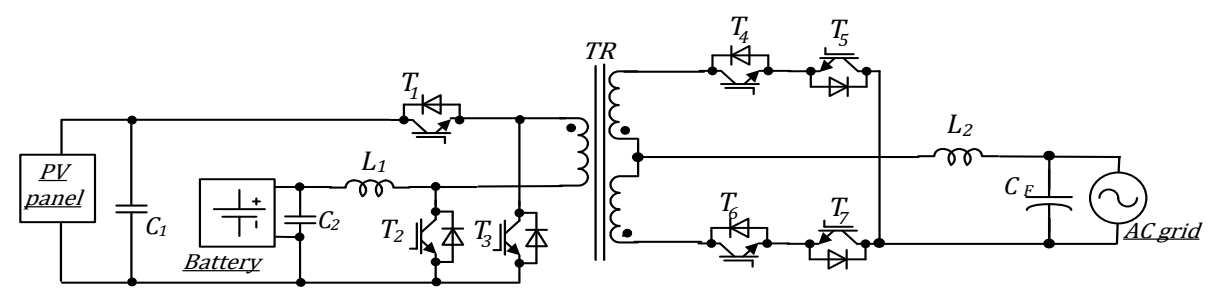

Figure 16.The topology of three port single stage DC-DC converter for PV applications [87]

\section{NOVEL TOPOLOGIES FOR RENEWABLE ENERGIES AND LOW VOLTAGE BESS INTEGRATION TO THE AC GRID}

Promising approach to store the extra energy when the load is light and to supply the load power during the period without or shortage of the source is to use Z-source inverter with integrated battery energy storage, the papers about this topology are summarized in [92]. The battery is connected in parallel to the quasi-Z-source capacitor (Figure 20), it is possible to control output power, and state of charge (SOC) of the battery at the same time by controlling the shoot-through (ST) duty ratio and modulation index.

There are three power sources or consumers - unidirectional DC source, battery, and the grid. If two power flows are controlled, the third one automatically takes the power difference. It is possible to use sinusoidal PWM (SPWM) based control for qZSI or specific qZSI-SVM. In [93] is shown that by using more advanced control technuique the efficiency can be increased by about 1 percent. In [94] it is shown that converter (Figure 17) can operate in battery charging mode in wide range as current in diode D is higher than zero but the discharging battery is limited to ensure that the converter operates in the continues conduction mode. Therefore, the battery discharge power ratio over the inverter output power and also the power of the inverter have limitations and also it is not possible to store energy in the battery from the grid.

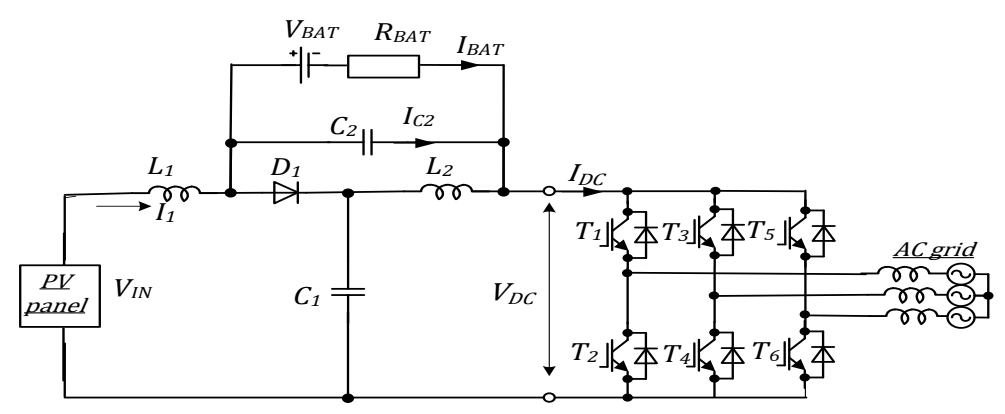

Figure 17. Battery energy stored quasi-Z source inverter (qZSI) [92]

The multilevel converter applications in power electronics becomes more and more wider because it can be achieved higher efficiency by using semiconductors with lower voltage ratings and better parameters. Important advantages of such converters are improved output power quality, better electromagnetic compatibility, lower switching losses. The diode clamped or neutral point lamped inverters are the most attractive solution for industrial applications [95]. In the paper [96] it is concluded, that the combination of the qZSI with NPC topology in comparison with traditional NPC multilevel converter have not voltage unbalance and common mode leakage current problems so also this kind of topology can be extended to utilize BESS.

As single stage buck boost inverter can be used impedance source network based inverter. The comprehensive analytical comparison is done in [98]. Many solutions based on Z-source and qZS networks exist but usually these solutions are unidirectional, bidirectional solutions is discussed in [99]-[102], [97] and [103]. Such topology (Figure 18) has reduced passive component ratings, less input semiconductors but more capacitors, continuous input current, and substantially wider regulation freedom. The efficiency is lower than 
of voltage source inverter but it seems to be interesting solution as single-stage solution or in combination with isolated DC-DC converter with bidirectional feature.

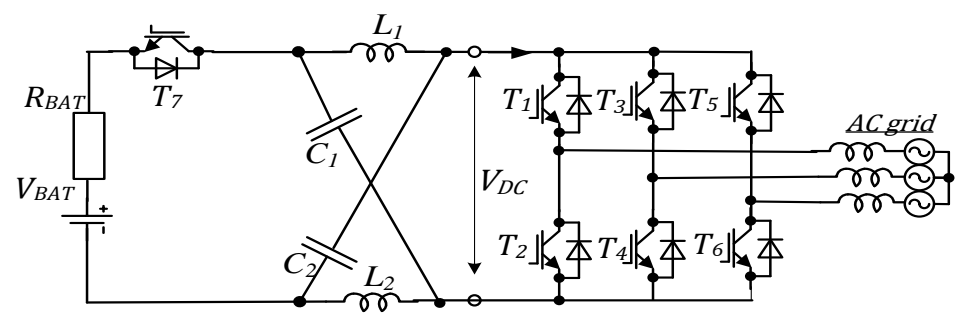

Figure 18. Scheme of the grid connected three phase bidirectional Z-source inverter [97]

In [101] is proposed bidirectional converter for control of the motor of the electric vehicle. It seems also possible to use modification of this converter for grid connected application (Figure 19). The main benefits are that the converter can provide bidirectional power flow and as this converter has small number of switches and two types of storages can be used. The usage of combination of supercapacitor and li-ion battery gives reduction of losses due to low series resistance of the supercapacitor and increased lifetime of battery due to smoother current waveforms.

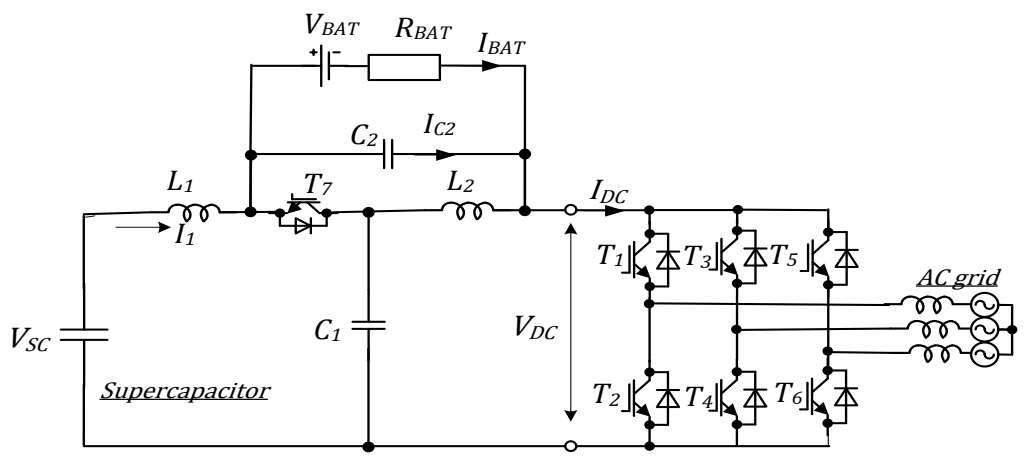

Figure 19. Bidirectional battery and supercapacitor energy stored quasi-Z Source Inverter

Operation modes of the converter also are shown in [101]. The grid and battery power can be regulated through switch $\mathrm{T} 7$ and the inverter (T1-T6). The power flow to the supercapacitors can be controlled indirectly by controlling difference between power from the battery and the AC grid.

The principle and characteristic of qZSI have been studied in [104]-[107]. The main equations is given in [108]. Parameters that are used for the control are modulation index of the inverter (M) and the shoot-through duty ratio (D). The relationship of the average currents in one switching period [101]:

$$
(1-2 \mathrm{D}) \overline{\mathrm{I}}_{\mathrm{SC}}+\mathrm{D} \overline{\mathrm{I}}_{\mathrm{BAT}}=\overline{\mathrm{I}}_{\mathrm{DC}}
$$

where are used the average currents supplied by the supercapacitor, battery and DC link (inverter) respectively. From the equation can be concluded that current flow can be controlled by meaning of D and modulation index $\mathrm{M}$ but the control loop is complex as change in one parameter leads to changes in others and is hard to get stable operation of the converter.

The converter have three operational modes: when the battery and supercapacitor supply power to the grid; when the power from the grid is transferred to the battery and supercapacitors; when the battery supplies power to the supercapacitors and grid. The battery current has low pulsations that is beneficial for long life of the battery. It is very complicated to get desired values of currents. This is a reason why in [101] is proposed to use frequency and time domain control of the converter. Beside these functions the controller must also control power factor, take into account state of charge of the battery and supercapacitor this leads 
to very complicated control system that must be implemented into powerful digital control system. It s possible also mode when the power from the battery is transferred to the supercapacitors and a grid.

It can be concluded that quasi Z-source inverter is suitable for bidirectional power flow to integrate battery in the AC grid and usage of this topology allows to control energy flow with inverters and only one additional semiconductor not only to the battery but also to the renewable energy generation system or other type of storage technology. The main drawback of the converter is complex control system to control energy flow as change in one parameter influences all of energy flows. Main advantages are reduced number of switches and small pulsations of the battery current.

\section{CONCLUSIONS}

Energy storage systems utilizing the state-of-the-art battery need to be efficient in the low voltage and high current range with a high power density. Therefore in this paper the highly efficient topologies of bidirectional isolated AC-DC converters for grid connected AC BESS have been overviewed. Bidirectional isolated AC-DC power converters are classified into single stage and two stage solutions.

Although single stage AC-DC isolated converter have less components, is cheaper and in some research reports it is shown god efficiency, this structure is not so popular due to complex optimization process and control algorithms to maintain necessary power quality. The number of research papers that published results of a study of isolated single stage bidirectional AC-DC converter is relatively low as usually is used high battery voltage concept with non-isolated converter. Can be concluded that this is a very attractive topic for research to make single-stage isolated AC-DC converter more efficient, to develop new control algorithms and topologies to attract interest from the industry. The application area that will promote the need for such structure will be usage of the electrical vehicle as grid connected energy storage.

The two stage structure consists of PFC AC-DC converter and single or two stage DC-DC converter. As bidirectional inverter can be used traditional bidirectional AC-DC converter or more advanced topologies. There are many papers that proposes improvements of isolated bidirectional DC-DC converters. For high-power applications, the full-bridge topology is known to be more suitable due to the lower voltage and current stress. To improve efficiency resonant topology often are employed and two-stage DC-DC converter topology.

The solutions that is proposed from the industry sometimes reaches higher efficiency and power density than the proposed from the researchers so there is still potential to the further improvement of the efficiency and power density, the use of wide band gap devices are very promising tool to do that. Mainly the AC-DC and DC-DC converters are addressed as separate parts so there is possibility for more integration of both these parts to improve performance of the converter. Very important becomes not only good topology but also optimization of the separate components, a new passive components, optimization of the heat sink, optimal placement of the components.

A more rapid development and real life implementation of the AC battery storage system concept can be reached if there were available topology that gives preference to this solution. The simulation based analysis of novel quasi $\mathrm{Z}$ source topology shows that this topology has low battery current ripple, only one additional switch and possibility to integrate different kind of storages and therefore is well suited for battery integration in AC grid. To wider use of this topology not only in research but also in practical applications new algorithms that can be more easily implemented in digital control systems must be developed and also more scientific analysis that reveals limitations, passive component selections, optimization and improvements of the topology.

\section{ACKNOWLEDGEMENTS}

The present research has been supported by the Latvian National Research Programme "LATENERGI".

\section{REFERENCES}

[1] "F. Chen, R. Burgos, and D. Boroyevich, 'Efficiency comparison of a single-phase grid-interface bidirectional AC/DC converter for DC distribution systems,' in 2015 IEEE Energy Conversion Congress and Exposition (ECCE), 2015, pp. 6261-6268."

[2] "S. Eren, M. Pahlevaninezhad, A. Bakhshai, and P. Jain, 'A Digital Current Control Technique for Grid-Connected AC/DC Converters Used for Energy Storage Systems,' IEEE Transactions on Power Electronics, vol. PP, no. 99, pp. 1-1, 2016.".

[3] "M. Naumann, R. C. Karl, C. N. Truong, A. Jossen, and H. C. Hesse, 'Lithium-ion Battery Cost Analysis in PVhousehold Application,' Energy Procedia, vol. 73, pp. 37-47, Jun. 2015.” . 
[4] "Bernhart W, Kruger FJ. Technology \& Market D rivers for Stationary and Automotive Battery Systems. Nice: Roland Berger Strategy Consultants, 2012 http://www.rechargebatteries.org/wp-content/ uploads/2013/04/Batteries-2012-Roland-Berger-Report1.pdf."

[5] "C. Restrepo, A. Salazar, H. Schweizer, and A. Ginart, 'Residential Battery Storage: Is the Timing Right?,' IEEE Electrification Magazine, vol. 3, no. 3, pp. 14-21, Sep. 2015.”.

[6] “'XALT ${ }^{\circledR} \quad 75$ Ah High Power (HP) Superior Lithium Ion Cell.' [Online]. Available: http://www.xaltenergy.com/images/pdfs/datasheets/XE_Data_75HP.pdf. [Accessed: 27-Oct-2016].”.

[7] "Z. Yu, H. Kapels, and K. F. Hoffmann, 'High Efficiency Bidirectional DC-DC Converter with Wide Input and Output Voltage Ranges for Battery Systems,' in Renewable Energy and Energy Management; Proceedings of PCIM Europe 2015; International Exhibition and Conference for Power Electronics, Intelligent Motion, 2015, pp. 1-8.”.

[8] "Products and Services - Storage Overview | Enphase." [Online]. Available: https://enphase.com/en-us/productsand-services/storage. [Accessed: 20-Oct-2016].

[9] "LEONARDO PRO 3000/48." [Online]. Available: http://www.tecnospot.eu/en/products/pvstorage?format=raw\&task=download\&fid=1678. [Accessed: $20-$ Oct-2016].

[10] Andreas Piepenbrink, "EU efficiency for home storage systems-a new and simple procedure." [Online]. Available: http://www.pv-magazine.de/fileadmin/uploads/Michael/e3dc_EU_Efficiency_of_battery_systems.pdf. [Accessed: 05-Oct-2016].

[11] M. F. de Melo, A. L. Kirsten, M. A. D. Costa, J. Garcia, and P. J. Quintana, "Bidirectional Flyback converter connected to the grid and applied to a distributed microgeneration and street lighting system," in 2014 IEEE Industry Application Society Annual Meeting, 2014, pp. 1-6.

[12] G. D. Andreescu, O. Cornea, N. Muntean, and E. Guran, "Bidirectional flyback inverter with low output voltage THD," in 2015 IEEE 10th Jubilee International Symposium on Applied Computational Intelligence and Informatics, 2015, pp. 95-99.

[13] F. Jauch and J. Biela, "Single-phase single-stage bidirectional isolated ZVS AC-DC converter with PFC," in Power Electronics and Motion Control Conference (EPE/PEMC), 2012 15th International, 2012, p. LS5d.1-1-LS5d.1-8.

[14] N. Weise and L. Doiron, "DQ current control of a bidirectional, isolated single-stage AC-DC converter," in 2014 IEEE Applied Power Electronics Conference and Exposition - APEC 2014, 2014, pp. 1888-1893.

[15] B. Koushki, P. Jain, and A. Bakhshai, "A bi-directional AC-DC converter for electric vehicle with no electrolytic capacitor," in 2016 IEEE 7th International Symposium on Power Electronics for Distributed Generation Systems (PEDG), 2016, pp. 1-8.

[16] T. Sundar and S. Sankar, "Modeling and simulation of closed loop controlled parallel cascaded buck boost converter inverter based solar system," International Journal of Power Electronics and Drive Systems (IJPEDS), vol. 6, no. 3, pp. 648-656, 2015.

[17] M. Wang, S. Guo, Q. Huang, W. Yu, and A. Q. Huang, "An Isolated Bi-directional Single-stage DC-AC Converter Using Wide-band-gap Devices with Novel Carrier-based Unipolar Modulation Technique under Synchronous Rectification," IEEE Transactions on Power Electronics, vol. PP, no. 99, pp. 1-1, 2016.

[18] X. Hu, K. J. Tseng, Y. Liu, S. Yin, and M. Zhang, "A high frequency isolated current-fed bidirectional DC/AC converter for grid-tied energy storage system," in 2013 IEEE ECCE Asia Downunder (ECCE Asia), 2013, pp. 291296.

[19] B. J. D. Vermulst, J. L. Duarte, C. G. E. Wijnands, and E. A. Lomonova, "Quad Active-Bridge Single-Stage Bidirectional Three-Phase AC-DC Converter with Isolation: Introduction and Optimized Modulation," IEEE Transactions on Power Electronics, vol. PP, no. 99, pp. 1-1, 2016.

[20] J. Everts, F. Krismer, J. V. den Keybus, J. Driesen, and J. W. Kolar, "Optimal ZVS Modulation of Single-Phase Single-Stage Bidirectional DAB AC-DC Converters," IEEE Transactions on Power Electronics, vol. 29, no. 8, pp. 3954-3970, Aug. 2014.

[21] F. Krismer, J. Biela, and J. W. Kolar, "A comparative evaluation of isolated bi-directional DC/DC converters with wide input and output voltage range," in Fourtieth IAS Annual Meeting. Conference Record of the 2005 Industry Applications Conference, 2005., 2005, vol. 1, pp. 599-606 Vol. 1.

[22] M. F. Vancu, T. Soeiro, J. Mühlethaler, J. W. Kolar, and D. Aggeler, "Comparative evaluation of bidirectional buck-type PFC converter systems for interfacing residential DC distribution systems to the smart grid," in IECON 2012 - 38th Annual Conference on IEEE Industrial Electronics Society, 2012, pp. 5153-5160.

[23] C. Marxgut, F. Krismer, D. Bortis, and J. W. Kolar, "Ultraflat Interleaved Triangular Current Mode (TCM) SinglePhase PFC Rectifier," IEEE Transactions on Power Electronics, vol. 29, no. 2, pp. 873-882, Feb. 2014.

[24] B. Singh, B. N. Singh, A. Chandra, K. Al-Haddad, A. Pandey, and D. P. Kothari, "A review of single-phase improved power quality AC-DC converters," IEEE Transactions on Industrial Electronics, vol. 50, no. 5, pp. 962 981, Oct. 2003.

[25] S. V. Brovanov and S. D. Egorov, "Review of AC voltage generation systems based on multilevel converters and photovoltaic cells," in 2013 14th International Conference of Young Specialists on Micro/Nanotechnologies and Electron Devices, 2013, pp. 275-278.

[26] M. Kasper, M. Antivachis, D. Bortis, J. W. Kolar, and G. Deboy, "4D-Interleaving of Isolated ISOP Multi-Cell Converter Systems for Single Phase AC/DC Conversion," in PCIM Europe 2016; International Exhibition and Conference for Power Electronics, Intelligent Motion, Renewable Energy and Energy Management, 2016, pp. 1-9.

[27] L. Xue, P. Mattavelli, D. Boroyevich, B. Hughes, and R. Burgos, "Efficiency optimized AC charging waveform for GaN bidirectional PHEV Battery Charger," in 2014 16th European Conference on Power Electronics and Applications (EPE'14-ECCE Europe), 2014, pp. 1-10. 
[28] J. S. Lai, L. Zhang, Z. Zahid, N. H. Tseng, C. S. Lee, and C. H. Lin, "A high-efficiency 3.3-kW bidirectional onboard charger," in Future Energy Electronics Conference (IFEEC), 2015 IEEE 2nd International, 2015, pp. 1-5.

[29] Y. W. Cho, W. J. Cha, J. M. Kwon, and B. H. Kwon, "High-Efficiency Bidirectional DAB Inverter Using a Novel Hybrid Modulation for Stand-Alone Power Generating System With Low Input Voltage," IEEE Transactions on Power Electronics, vol. 31, no. 6, pp. 4138-4147, Jun. 2016.

[30] S. Talbi, A. M. Mabwe, and A. E. Hajjaji, "Control of a bidirectional dual active bridge converter for charge and discharge of a Li-Ion Battery," in IECON 2015 - 41st Annual Conference of the IEEE Industrial Electronics Society, 2015, pp. 000849-000856.

[31] M. H. Ryu, H. S. Kim, J. W. Baek, H. G. Kim, and J. H. Jung, "Effective Test Bed of 380-V DC Distribution System Using Isolated Power Converters," IEEE Transactions on Industrial Electronics, vol. 62, no. 7, pp. 45254536, Jul. 2015.

[32] E. S. Kim, J. H. Park, J. S. Joo, S. M. Lee, K. Kim, and Y. S. Kong, "Bidirectional DC-DC converter using secondary LLC resonant tank," in 2015 IEEE Applied Power Electronics Conference and Exposition (APEC), 2015, pp. 2104-2108.

[33] T. Jiang, X. Chen, J. Zhang, and Y. Wang, "Bidirectional LLC resonant converter for energy storage applications," in 2013 Twenty-Eighth Annual IEEE Applied Power Electronics Conference and Exposition (APEC), 2013, pp. 1145-1151.

[34] N. M. L. Tan, T. Abe, and H. Akagi, "Topology and application of bidirectional isolated dc-dc converters," in 2011 IEEE 8th International Conference on Power Electronics and ECCE Asia (ICPE ECCE), 2011, pp. 1039-1046.

[35] J. Hiltunen, V. Väisänen, and P. Silventoinen, "A bidirectional current-fed resonant push-pull converter for low voltage, high current applications," in 2013 IEEE Energy Conversion Congress and Exposition, 2013, pp. 47704774 .

[36] Z. Wang and H. Li, "A Soft Switching Three-phase Current-fed Bidirectional DC-DC Converter With High Efficiency Over a Wide Input Voltage Range," IEEE Transactions on Power Electronics, vol. 27, no. 2, pp. 669684, Feb. 2012.

[37] P. Xuewei and A. K. Rathore, "Current-Fed Soft-Switching Push Pull Front-End Converter-Based Bidirectional Inverter for Residential Photovoltaic Power System," IEEE Transactions on Power Electronics, vol. 29, no. 11, pp. 6041-6051, Nov. 2014.

[38] S. Bal, A. K. Rathore, and D. Srinivasan, "Naturally Clamped Snubberless Soft-Switching Bidirectional CurrentFed Three-Phase Push Pull DC/DC Converter for DC Microgrid Application," IEEE Transactions on Industry Applications, vol. 52, no. 2, pp. 1577-1587, Mar. 2016.

[39] P. Xuewei, A. K. Rathore, and U. R. Prasanna, "Novel Soft-Switching Snubberless Naturally Clamped Current-Fed Full-Bridge Front-End-Converter-Based Bidirectional Inverter for Renewables, Microgrid, and UPS Applications," IEEE Transactions on Industry Applications, vol. 50, no. 6, pp. 4132-4141, Nov. 2014.

[40] E. J. Ha, Y. S. Noh, C. Y. Won, and M. S. Oh, "Loss analysis of current-fed two inductor bi-directional DC-DC converter using resonance," in 2015 IEEE International Telecommunications Energy Conference (IN TELEC), 2015, pp. 1-6.

[41] A. Mehdipour and S. Farhangi, "Comparison of three isolated bi-directional DC/DC converter topologies for a backup photovoltaic application," in 2011 2nd International Conference on Electric Power and Energy Conversion Systems (EPECS), 2011, pp. 1-5.

[42] A. Patel, "A new bidirectional DC-DC converter for fuel cell, solar cell and battery systems," in 2016 IEEE Applied Power Electronics Conference and Exposition (APEC), 2016, pp. 150-155.

[43] "HV BCM Bus Converter Module | Vicor Corporation." [Online]. Available: http://www.vicorpower.com/dcdc/isolated-fixed-ratio/hv-bus-converter-module. [Accessed: 27-Oct-2016].

[44] D. Costinett, H. Nguyen, R. Zane, and D. Maksimovic, "GaN-FET based dual active bridge DC-DC converter," in 2011 Twenty-Sixth Annual IEEE Applied Power Electronics Conference and Exposition (APEC), 2011, pp. 14251432.

[45] F. Xue, R. Yu, S. Guo, W. Yu, and A. Q. Huang, "Loss analysis of GaN devices in an isolated bidirectional DC-DC converter," in 2015 IEEE 3rd Workshop on Wide Bandgap Power Devices and Applications (WiPDA), 2015, pp. 201-205.

[46] C. Ma, K. Yoshida, and K. Honda, "An isolated bidirectional resonant LLC DC-DC converter for distributed power systems," in Society of Instrument and Control Engineers of Japan (SICE), 2015 54th Annual Conference of the, 2015, pp. 894-899.

[47] D. De, A. Castellazzi, and A. Lamantia, "1.2kW dual-active bridge converter using SiC power MOSFETs and planar magnetics," in 2014 International Power Electronics Conference (IPEC-Hiroshima 2014 - ECCE ASIA), 2014, pp. 2503-2510.

[48] D. Gunasekaran and L. Umanand, "Integrated magnetics based multi-port bidirectional DC-DC converter topology for discontinuous-mode operation," IET Power Electronics, vol. 5, no. 7, pp. 935-944, Aug. 2012.

[49] G. Liu, D. Li, Y. Jang, and J. Zhang, "Over 300kHz GaN device based resonant bidirectional DCDC converter with integrated magnetics," in 2016 IEEE Applied Power Electronics Conference and Exposition (APEC), 2016, pp. 595-600.

[50] P. Xuewei, A. K. Rathore, and U. R. Prasanna, "Novel Soft-Switching Snubberless Naturally Clamped Current-Fed Full-Bridge Front-End-Converter-Based Bidirectional Inverter for Renewables, Microgrid, and UPS Applications," IEEE Transactions on Industry Applications, vol. 50, no. 6, pp. 4132-4141, Nov. 2014. 
[51] T. F. Wu, J. G. Yang, C. L. Kuo, and Y. C. Wu, "Soft-Switching Bidirectional Isolated Full-Bridge Converter With Active and Passive Snubbers," IEEE Transactions on Industrial Electronics, vol. 61, no. 3, pp. 1368-1376, Mar. 2014.

[52] S. Dusmez, A. Khaligh, and A. Hasanzadeh, "A Zero-Voltage-Transition Bidirectional DC/DC Converter," IEEE Transactions on Industrial Electronics, vol. 62, no. 5, pp. 3152-3162, May 2015.

[53] A. Chub, R. Kosenko, A. Blinov, V. Ivakhno, V. Zamaruiev, and B. Styslo, "Full soft-switching bidirectional current-fed DC-DC converter," in 2015 56th International Scientific Conference on Power and Electrical Engineering of Riga Technical University (RTUCON), 2015, pp. 1-6.

[54] F. L. Tofoli, D. d C. Pereira, W. J. de Paula, and D. d S. O. Júnior, "Survey on non-isolated high-voltage step-up dc-dc topologies based on the boost converter," IET Power Electronics, vol. 8, no. 10, pp. 2044-2057, 2015.

[55] W. Li, X. Lv, Y. Deng, J. Liu, and X. He, "A Review of Non-Isolated High Step-Up DC/DC Converters in Renewable Energy Applications," in Twenty-Fourth Annual IEEE Applied Power Electronics Conference and Exposition, 2009. APEC 2009, 2009, pp. 364-369.

[56] H. Wu, K. Sun, L. Chen, L. Zhu, and Y. Xing, "High Step-Up/Step-Down Soft-Switching Bidirectional DC-DC Converter With Coupled-Inductor and Voltage Matching Control for Energy Storage Systems," IEEE Transactions on Industrial Electronics, vol. 63, no. 5, pp. 2892-2903, Maijs 2016.

[57] R.-J. Wai and R.-Y. Duan, "High Step-up Coupled-inductor-based Converter Using Bi-direction Energy Transmission," in 2005 IEEE 36th Power Electronics Specialists Conference, 2005, pp. 406-412.

[58] S. U. Hasan, J. Liu, F. Liu, and H. Zhang, "Practical design considerations for coupled inductor based bi-directional Converters of high voltage ratio," in 2013 IEEE International Conference of IEEE Region 10 (TENCON 2013), 2013, pp. 1-5.

[59] M. Aamir, S. Mekhilef, and H. J. Kim, "High-Gain Zero-Voltage Switching Bidirectional Converter With a Reduced Number of Switches," IEEE Transactions on Circuits and Systems II: Express Briefs, vol. 62, no. 8, pp. 816-820, Aug. 2015.

[60] L. Chen, H. Wu, Y. Xing, and X. Xiao, "Performance evaluation of a $1 \mathrm{~kW}$ non-isolated high step-up/step-down bidirectional converter for distributed battery storage system," in 2015 IEEE 2nd International Future Energy Electronics Conference (IFEEC), 2015, pp. 1-5.

[61] S. Xiong and S. C. Tan, "Cascaded High-Voltage-Gain Bidirectional Switched-Capacitor DC-DC Converters for Distributed Energy Resources Applications," IEEE Transactions on Power Electronics, vol. 32, no. 2, pp. 12201231, Feb. 2017.

[62] H. Wu, Y. Lu, L. Chen, P. Xu, X. Xiao, and Y. Xing, "High step-up/step-down non-isolated BDC with built-in DCtransformer for energy storage systems," IET Power Electronics, vol. 9, no. 13, pp. 2571-2579, 2016.

[63] K. Filsoof and P. W. Lehn, "A Bidirectional Modular Multilevel DC-DC Converter of Triangular Structure," IEEE Transactions on Power Electronics, vol. 30, no. 1, pp. 54-64, Jan. 2015.

[64] S. Busquets-Monge, S. Alepuz, and J. Bordonau, "A Bidirectional Multilevel Boost-Buck DC-DC Converter," IEEE Transactions on Power Electronics, vol. 26, no. 8, pp. 2172-2183, Aug. 2011.

[65] M. Kwon, S. Oh, and S. Choi, "High Gain Soft-Switching Bidirectional DC-DC Converter for Eco-Friendly Vehicles," IEEE Transactions on Power Electronics, vol. 29, no. 4, pp. 1659-1666, Apr. 2014.

[66] H. W. Seong, H. S. Kim, K. B. Park, G. W. Moon, and M. J. Youn, "High Step-Up DC-DC Converters Using ZeroVoltage Switching Boost Integration Technique and Light-Load Frequency Modulation Control," IEEE Transactions on Power Electronics, vol. 27, no. 3, pp. 1383-1400, Mar. 2012.

[67] L. C. Miranda, R. R. Sanhueza, G. M. López, S. Fingerhuth, S. A. Mussa, and D. Ruiz-Caballero, "High-gain symmetrical hybrid multilevel DC-AC converters - Single phase circuits," in 2013 Brazilian Power Electronics Conference, 2013, pp. 161-168.

[68] O. Ray, S. Mishra, A. Joshi, V. Pradeep, and A. Tiwari, "Implementation and control of a bidirectional high-gain transformer-less standalone inverter," in 2012 IEEE Energy Conversion Congress and Exposition (ECCE), 2012, pp. 3233-3240.

[69] V. F. Pires, D. Foito, and J. F. Martins, "Bidirectional DC-DC converter with high voltage gain for the charge/discharge control of storage systems," in 2016 15th Biennial Baltic Electronics Conference (BEC), 2016, pp. 191-194.

[70] J. Zakis, A. Suzdalenko, N. Barath, and O. Husev, "Transformerless cuk derived high boost DC-AC converter for dual PV applications simulation study," in 2016 IEEE 8th International Power Electronics and Motion Control Conference (IPEMC-ECCE Asia), 2016, pp. 1128-1133.

[71] C. Zhao, S. D. Round, and J. W. Kolar, "An Isolated Three-Port Bidirectional DC-DC Converter With Decoupled Power Flow Management," IEEE Transactions on Power Electronics, vol. 23, no. 5, pp. 2443-2453, Sep. 2008.

[72] N. Zhang, D. Sutanto, and K. M. Muttaqi, "A review of topologies of three-port DC-DC converters for the integration of renewable energy and energy storage system," Renewable and Sustainable Energy Reviews, vol. 56, pp. 388-401, Apr. 2016.

[73] V. Fernão Pires, E. Romero-Cadaval, D. Vinnikov, I. Roasto, and J. F. Martins, "Power converter interfaces for electrochemical energy storage systems - A review," Energy Conversion and Management, vol. 86, pp. 453-475, Oct. 2014

[74] J. Zeng, W. Qiao, and L. Qu, "An Isolated Three-Port Bidirectional DC - DC Converter for Photovoltaic Systems With Energy Storage," IEEE Transactions on Industry Applications, vol. 51, no. 4, pp. 3493-3503, Jul. 2015.

[75] H. Zhu, D. Zhang, H. S. Athab, B. Wu, and Y. Gu, "PV Isolated Three-Port Converter and Energy-Balancing Control Method for PV-Battery Power Supply Applications," IEEE Transactions on Industrial Electronics, vol. 62, no. 6, pp. 3595-3606, Jun. 2015. 
[76] Z. Ding, C. Yang, Z. Zhang, C. Wang, and S. Xie, "A Novel Soft-Switching Multiport Bidirectional DC \#x2013;DC Converter for Hybrid Energy Storage System," IEEE Transactions on Power Electronics, vol. 29, no. 4, pp. 1595-1609, Apr. 2014.

[77] K. Shreelekha and S. Arulmozhi, "Multiport isolated bidirectional DC-DC converter interfacing battery and supercapacitor for hybrid energy storage application," in 2016 International Conference on Electrical, Electronics, and Optimization Techniques (ICEEOT), 2016, pp. 2763-2768.

[78] W. Jiang and B. Fahimi, "Multiport Power Electronic Interface \#x2014;Concept, Modeling, and Design," IEEE Transactions on Power Electronics, vol. 26, no. 7, pp. 1890-1900, Jul. 2011.

[79] H. Tao, J. L. Duarte, and M. A. M. Hendrix, "Three-Port Triple-Half-Bridge Bidirectional Converter With ZeroVoltage Switching," IEEE Transactions on Power Electronics, vol. 23, no. 2, pp. 782-792, Mar. 2008.

[80] J. L. Duarte, M. Hendrix, and M. G. Simoes, "Three-Port Bidirectional Converter for Hybrid Fuel Cell Systems," IEEE Transactions on Power Electronics, vol. 22, no. 2, pp. 480-487, Mar. 2007.

[81] Y. M. Chen, A. Q. Huang, and X. Yu, "A High Step-Up Three-Port DC-DC Converter for Stand-Alone PV/Battery Power Systems," IEEE Transactions on Power Electronics, vol. 28, no. 11, pp. 5049-5062, Nov. 2013.

[82] D. Liu and H. Li, "A ZVS Bi-Directional DC-DC Converter for Multiple Energy Storage Elements," IEEE Transactions on Power Electronics, vol. 21, no. 5, pp. 1513-1517, Sep. 2006.

[83] H. Tao, A. Kotsopoulos, J. L. Duarte, and M. A. M. Hendrix, "Transformer-Coupled Multiport ZVS Bidirectional DC-DC Converter With Wide Input Range," IEEE Transactions on Power Electronics, vol. 23, no. 2, pp. 771-781, Mar. 2008.

[84] C. Zhao, S. D. Round, and J. W. Kolar, “An Isolated Three-Port Bidirectional DC-DC Converter With Decoupled Power Flow Management,” IEEE Transactions on Power Electronics, vol. 23, no. 5, pp. 2443-2453, Sep. 2008.

[85] H. Krishnaswami and N. Mohan, "Three-Port Series-Resonant DC-DC Converter to Interface Renewable Energy Sources With Bidirectional Load and Energy Storage Ports," IEEE Transactions on Power Electronics, vol. 24, no. 10, pp. 2289-2297, Oct. 2009.

[86] P. H. Tseng, J. F. Chen, T. J. Liang, and H. W. Liang, "A novel high step-up three-port converter," in 2014 International Power Electronics and Application Conference and Exposition, 2014, pp. 21-25.

[87] J. Zeng, W. Qiao, C. Wei, and L. Qu, "A soft-switched three-port single-stage inverter for photovoltaic-battery systems," in 2015 IEEE Energy Conversion Congress and Exposition (ECCE), 2015, pp. 4568-4573.

[88] H. R. Teymour, D. Sutanto, K. M. Muttaqi, and P. Ciufo, "Solar PV and Battery Storage Integration using a New Con Figureuration of a Three-Level NPC Inverter With Advanced Control Strategy," IEEE Transactions on Energy Conversion, vol. 29, no. 2, pp. 354-365, Jun. 2014.

[89] C. Li et al., "A $2 \mathrm{~kW}$ Gallium Nitride based switched capacitor three-port inverter," in The 1st IEEE Workshop on Wide Bandgap Power Devices and Applications, 2013, pp. 119-124.

[90] S. D. G. Jayasinghe, D. M. Vilathgamuwa, and U. K. Madawala, "Diode-Clamped Three-Level Inverter-Based Battery/Supercapacitor Direct Integration Scheme for Renewable Energy Systems," IEEE Transactions on Power Electronics, vol. 26, no. 12, pp. 3720-3729, Dec. 2011.

[91] D. Stepins and J. Huang, "Effects of Switching Frequency Modulation on Input Power Quality of Boost Power Factor Correction Converter," International Journal of Power Electronics and Drive Systems (IJPEDS), vol. 8, no. 2, pp. 882-899, 2017.

[92] Y. Liu, H. Abu-Rub, B. Ge, F. Blaabjerg, O. Ellabban, and P. C. Loh, "Energy Stored Z-Source/Quasi-Z-Source Inverters," in Impedance Source Power Electronic Converters, Wiley-IEEE Press, 2016, pp. 424-.

[93] J. Liu, S. Jiang, D. Cao, and F. Z. Peng, "A Digital Current Control of Quasi-Z-Source Inverter With Battery," IEEE Transactions on Industrial Informatics, vol. 9, no. 2, pp. 928-937, May 2013.

[94] B. Ge et al., "An Energy-Stored Quasi-Z-Source Inverter for Application to Photovoltaic Power System," IEEE Transactions on Industrial Electronics, vol. 60, no. 10, pp. 4468-4481, Oct. 2013.

[95] K. K. Gupta, A. Ranjan, P. Bhatnagar, L. K. Sahu, and S. Jain, "Multilevel Inverter Topologies With Reduced Device Count: A Review," IEEE Transactions on Power Electronics, vol. 31, no. 1, pp. 135-151, Jan. 2016.

[96] O. Husev et al., "Comparison of Impedance-Source Networks for Two and Multilevel Buck -Boost Inverter Applications," IEEE Transactions on Power Electronics, vol. 31, no. 11, pp. 7564-7579, Nov. 2016.

[97] S. Rajakaruna and B. Zhang, "Design and control of a bidirectional Z-Source inverter," in Power Engineering Conference, 2009. AUPEC 2009. Australasian Universities, 2009, pp. 1-6.

[98] O. Husev et al., "Comparison of Impedance-Source Networks for Two and Multilevel Buck -Boost Inverter Applications," IEEE Transactions on Power Electronics, vol. 31, no. 11, pp. 7564-7579, Nov. 2016.

[99] S. Asghari-Gorji and M. Ektesabi, "Input current ripples cancellation in bidirectional switched-inductor quasi-Zsource inverter using coupled inductors," in Power Engineering Conference (AUPEC), 2015 Australasian Universities, 2015, pp. 1-6.

[100] J. Zakis, D. Vinnikov, I. Roasto, and L. Ribickis, "Quasi-Z-source inverter based bi-directional DC/DC converter: Analysis of experimental results," in 2011 7th International Conference-Workshop Compatibility and Power Electronics (CPE), 2011, pp. 394-399.

[101] S. Hu, Z. Liang, D. Fan, and X. He, "Hybrid Ultracapacitor-Battery Energy Storage System Based on Quasi-Zsource Topology and Enhanced Frequency Dividing Coordinated Control for EV," IEEE Transactions on Power Electronics, vol. 31, no. 11, pp. 7598-7610, Nov. 2016.

[102] T. Sato, T. Shimo, T. Takiguchi, and H. Koizumi, "Bidirectional cascaded quasi-Z-source DC-DC converter," in IECON 2014 - 40th Annual Conference of the IEEE Industrial Electronics Society, 2014, pp. 1270-1276. 
[103] J. Rabkowski, "The bidirectional Z-source inverter for energy storage application," in 2007 European Conference on Power Electronics and Applications, 2007, pp. 1-10.

[104] Y. P. Siwakoti, F. Z. Peng, F. Blaabjerg, P. C. Loh, G. E. Town, and S. Yang, "Impedance-Source Networks for Electric Power Conversion Part II: Review of Control and Modulation Techniques," IEEE Transactions on Power Electronics, vol. 30, no. 4, pp. 1887-1906, Apr. 2015.

[105] Y. Li, J. Anderson, F. Z. Peng, and D. Liu, "Quasi-Z-Source Inverter for Photovoltaic Power Generation Systems," in Twenty-Fourth Annual IEEE Applied Power Electronics Conference and Exposition, 2009. APEC 2009, 2009, pp. 918-924.

[106] A. Zakerian and D. Nazarpour, "New Hybrid Structure Based on Improved Switched Inductor Z-Source and Parallel Inverters for Renewable Energy Systems," International Journal of Power Electronics and Drive Systems (IJPEDS), vol. 6, no. 3, pp. 636-647, 2015.

[107] S. Vasudevan, M. Aravindan, V. Balaji, and M. Arumugam, "Experimental Verification of Single Phase Z Source Inverter for Photovoltaic Applications," International Journal of Power Electronics and Drive Systems (IJPEDS), vol. 9, no. 2, pp. 698-703, 2018.

[108] J. Anderson and F. Z. Peng, "Four quasi-Z-Source inverters," in 2008 IEEE Power Electronics Specialists Conference, 2008, pp. 2743-2749. 